\title{
Serebral palside yürüme bozuklukları ve tedavi yöntemi seçimi
}

\author{
Gait disorders in cerebral palsy and selection of treatment method
}

\author{
Ozan Ali Erdal, Muharrem İnan
}

Ortopediatri İstanbul, Çocuk Ortopedi Akademisi, İstanbul, Türkiye

\begin{abstract}
SP'li çocuklarda gözlemlediğimiz yürüme bozukluklarının tamamını sınıflandırmaya yeterli olan bir sistem henüz yayımlanmamıştır. Ancak, sıklıkla karşılaşılan yürüme bozuklukları, tedaviyi yönlendirmek, iletişimi geliştirmek ve tedavi etkinliğini takip etmek için birkaç başlık altında sınıflandırılmıştır. Bu sınıflamaların temelinde her zaman olduğu gibi ayrıntılı hasta öyküsü, fizik muayene, yürümenin gözlemsel analizi yatar. Ayrıca EMG ve bilgisayarlı yürüme analizleri, hekimin vardığı sonucun sağlamasında, gözlemlerimizden kaçan ayrıntıların tespitinde çok önemli roller oynamaktadır. Tüm bu yöntemler sayesinde yürüme bozuklukları, etkiledikleri yürüme fazı, anatomik düzlem, EMG verileri ve karakteristik kinetik ve kinematik özellikleri kullanılarak sınıflanabilmektedir. Her sınıflama çabası farklı bir açıdan baksa da genellikle literatürde paylaşılan yürüme bozukluğu tipleri benzerdir. Bunların ışığında da yürümeyi bozan birincil, ikincil ve üçüncül nedenler belirlenebilmekte ve bunlardan özellikle ilk ikisi hedeflenerek tedavi planları yapılabilmektedir. Ancak, tüm sınıflandırmalar ve isimlendirmeler bir serebral palsi hastasında olabilecek tüm yürüme şekillerini açıklamaya tam yetmez. $\mathrm{Bu}$ nedenle, tanımlar ve tiplendirmeler arasında geçişler ve kombinasyonlar olabileceği akılda tutulmalıdır.
\end{abstract}

Anahtar sözcükler: serebral palsi; yürüme; yürüme analizi

\begin{abstract}
A system which sufficiently classify the entire gait disturbances observed in children with cerebral palsy has not been published yet. However, frequently encountered gait disturbances are classified under several headings to guide treatment, improve communication, and monitor treatment effectiveness. As always, basis of these classifications count on detailed patient history, physical examination, and observational analysis of gait. In addition, EMG and computerized gait analyzes play a crucial role in confirming the decision of the physician and in determining the details that escape our observations. With all these methods, gait disturbances can be classified using their gait phase, anatomical plane, EMG data and characteristic kinetic and kinematic characteristics. Although each classification effort has its own point of view, different type of gait disorders commonly shared in the literature, are similar. In the light of these information the primary, secondary and tertiary causes that disturb the walking can be determined and treatment plans can be made especially by targeting the first two. However, all classifications and nomenclatures do not adequately describe all the walking patterns that may be in the case of a cerebral palsy patient. For this reason, it should be kept in mind that there may be transitions and combinations between definitions and types.
\end{abstract}

Key words: cerebral palsy; gait; gait analysis
$\mathbf{N}$ ormal bir yürüme fonksiyonu, kas iskelet sisteminin en komplike görevlerinden birisidir. En az enerjiyi harcayan, dengeli ve etkili normal bir yürüme, motor korteks, bazal gangliyonlar, serebellum, omurilik ve omurilik reflekslerinin yanı sıra, sağlam bir kas dokusu ile basınç ve pozisyon algısı gibi duyusal geri bildirimlerin, bir arada karmaşık ama uyumlu bir etkileşim içerisinde çalışmasıyla elde edilebilir. Doğal olarak, serebral palsi (SP) hastalarında bu sistemlerden birkaçı birden bozulduğu için yürüme de etkilenmektedir. Özellikle fonksiyonel olarak daha az etkilenmiş, yürüyebilen, diplejik veya hemiplejik hastalarda yürüme bozuklukları gerek çocuk gerekse aile için öncelikli problem olmakta ve temel beklenti çocuğun olabildiğince bağımsız ve normale yakın bir yürümeye kavuşabilmesi haline gelmektedir. Bu beklentilerin çocuğun potansiyeline göre başarılı bir şekilde karşılanması için yürüme bozukluklarına sistematik bir bakış açısı geliştirmek, tedavi planını da bu doğrultuda yaparak son çalışmaların ışığında tedavi kararını vermek, hekimin temel görevleri arasındadır.

- Illetişim adresi: Prof. Dr. Muharrem İnan, Hakkı Yeten Cad. Süleyman Seba Kompleksi 10/D, Fulya, Şişli, İstanbul Tel: 0212 - 2969450 e-posta: muharreminan@hotmail.com

- Geliș tarihi: 1 Ekim $2018 \quad$ Kabul tarihi: 1 Ekim 2018 
SP hastalarında yürüme bozukluklarının tanımlanması ve sınıflandırılması amacıyla pek çok yayın yapılmıştır. Bunlardaki temel amaç, bozukluklar ile ilgili hekimler arası iletişimi geliştirmek, klinik karar verme ve tedaviyi belirlemede yol gösterici olmak ve tedavi sonrası sonuçları kıyaslayarak değerlendirmektir. ilk zamanlarda yapılan yürüme bozukluğu sınıflamaları daha çok niteliksel veya öznel hekim tecrübelerine dayanmaktaydı. ${ }^{[1,2]}$ Bu sınıflandırmalarda fizik muayene ve gözlemsel yürüme değerlendirmeleri kullanılmaktaydı. Ayrıca, anestezi altında yapılan muayenelerin de sınıflandırmada ve tedavi kararında değeri gösterilmişti. ${ }^{[3]}$ Daha sonra, bunlara ek olarak bilgisayar destekli yürüme veya hareket analizinin kinetik ve kinematik verileri ile EMG ölçümlerinin eklenmesi sayesinde, daha nesnel ölçütlere dayanan sınıflandırmalar geliştirilmeye çalışılmış ama yine de halen hekim tarafından yorumlanmaları gerektiği için öznel özellikleri de kısmen korunmuştur. ${ }^{[2,4]}$ Sınıflandırmalar geliştirildikçe, analitik veriler ışığında tedavi endikasyonlarının değiştiği gözlenmiş ve konunun önemi daha iyi anlaşılmıştır. ${ }^{[4,5]}$ Öte yandan, SP'nin çocuklarda meydana getirdiği bozukluklar çok fazla farklılık gösterdiği ve bunun yürümede de çok değişik şekillerde yansımaları olacağı için, sınıflandırmaların SP'de görülen tüm olası yürüme bozukluklarını kapsaması pratik olarak mümkün gözükmemektedir. Ayrıca, ortaya atılan sınıflandırmaların tekrar edilebilirliği ve güvenilirliği de kanıtlanmamıştır. ${ }^{[2,5]}$ Ancak, yürümedeki bozukluların sınıflandırılması için yapılan tüm çabaların sonucunda, SP'de sıkça karşılaşılan birkaç yürüme şeklinin olduğu da literatürde kabul görmüştür. Bunlar temel bir şablon olarak kullanıldığında oldukça yararlıdır ama unutulmamalıdır ki tüm bu yürüme şekillerinin kombinasyonları, varyasyonları ve sınıflar arasında geçişler ile karşılaşmak da doğaldır. ${ }^{[6,7]}$

Bir yürüme bozukluğunu değerlendirirken bozukluğun birincil, ikincil ve üçüncül nedenlerinin ayrımına varmak gereklidir. ${ }^{[3,6]}$ Sınıflandırmalar da bunların ayırt edilmesinde ve tedavinin planlanmasında yol gösterici olmalıdır. Yürüme bozukluğuna yol açan birincil nedenler, hastalığın doğası gereği sinir sisteminden kaynaklı olup çocukta gevşeklik, spastisite, pozisyon algısında ve kas kontrollerinde bozukluk olarak karşımıza çıkar. Bu bozukluklar genellikle fizik tedavi, nörolojik ve beyin cerrahisi tedavi yöntemleri ile tedavi edilirken kaslardaki spastisiteye yönelik olarak ortopedide başvurulan botulinum toksin uygulamaları da yine bu birincil patolojilere yöneliktir. ikincil nedenler ise dengesiz uyarılara ve yüklenmelere neden olan uzun süreli birincil problemlerin sonucunda kaslardaki kontraktürler, kemiklerdeki yapısal bozulmalar ve ekstremitelerdeki dizilim kusurları olarak karşımıza çıkar. Bu bozukluklar ise temel olarak ortopedik müdahaleler ile düzeltilebilmektedir. Bunlara örnek olarak ise ayak bileği ekin kontraktüründe başvurulan Aşil tendon fraksiyonel uzatılması veya dizde fleksiyon kontraktürlerinde başvurulan femur distali ekstansiyon osteotomileri verilebilir. Birincil ve ikincil nedenler hastanın yürümesini bozduğunda, bunları telafi ederek yürümeyi olabildiğince etkili bir şekilde devam ettirebilmek için ekstremitelerde, gövdede veya omurgada oluşan farklılıklar üçüncül nedenlerin temelini oluşturur. Telafi amacıyla vücudun yarattığı bu etkiler bazen devamlılık arz edebilir ve kişinin yürümesini etkili bir şekilde daha iyi hale getirebilir. Bu değişiklikler kimi durumlarda kabul edilebilir olup ek müdahale gerektirmeyebilir. Bazı durumlarda ise bu üçüncül değişiklikler de telafide yetersiz kalır ve hatta yürümenin etkinliğini daha da azaltarak kalıcı deformitelere yol açabilir. Bu gibi durumlarda da öncelikle birincil ve ikincil nedenlere yönelik tedavi planlaması yapılmalı ve bunların üçüncül problemleri ortadan kaldırabileceği akılda tutulmalıdır. Doğrudan üçüncül nedenlere odaklanan tedaviler yürümeyi düzeltemeyeceği gibi daha da bozma riskini taşır. Yürümeyi bozan üçüncül nedenlere, birincil veya ikincil nedenlerle diz fleksiyon kontraktürü olan diplejik bir hastada gelişen anterior pelvik eğim örnek olarak verilebilir.

Yürüme bozukluğu nedenlerinin birincil, ikincil ve üçüncül nedenler olarak ayrımına varıldıktan sonra sıkça karşılaşılan yürüme bozukluklarının sınıflamasına geçilebilir. SP'li hastalarda sıkça karşılaşılan yürüme bozuklukları üç düzlemde incelenebilir. ${ }^{[6]}$ Sagittal düzlemdeki bozukluklar sıçrayıcı, çömelerek veya sert yürüyüşler olarak sınıflanabilirken; transvers düzlemdeki problemler internal, eksternal veya nötral dizilim şeklinde sınıflanabilir. Öte yandan koronal düzlemdeki yürüme bozuklukları kemiklerde varus ve valgus dizilim kusurlarından kaynaklanabilmekte ise de SP'de bunların yerine daha sıklıkla sagittal ve transvers düzlem problemlerinin koronal düzleme izdüşümleri şeklinde karşımıza çıkar.

\section{SEREBRAL PALSIDE YÜRÜMENIN SAGITTAL DÜZLEMDEKI BOZUKLUKLARI}

Yürüme bozukluklarının sınıflandırılması ile ilgili çabaların çoğunda hekimler sagittal düzlemdeki bozukluklara odaklanmıştır. ${ }^{[2]}$ Bunun nedenlerinin başında, gözlemsel olarak daha kolay ayırt edilmeleri yatar. Bu bozukluklar basitçe; sıçrayarak yürüme, çömelerek veya diz bükük yürüme ve sert diz yürüyüşü olarak sınıflanabilir. Sıçrayarak yürüme ve çömelerek yürümeler, yürümenin duruş fazında kendilerini belli ederken; sert diz 


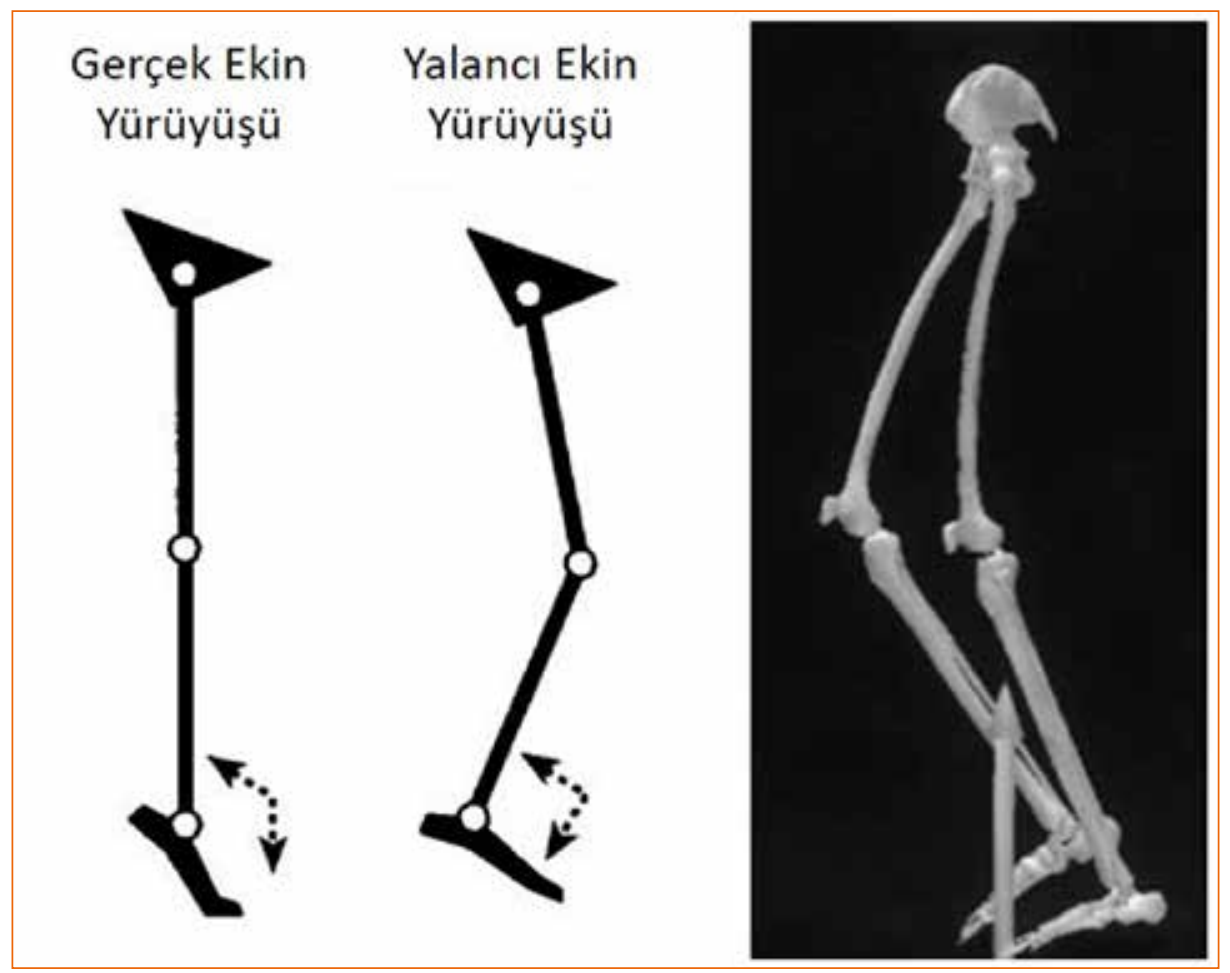

Şekil 1. Ayak bileğinde gerçek ekin pozisyonunda yürüme ile yalancı ekin yürüyüşü çizimler ile gösterilmiştir. Yalancı ekin pozisyonuna birincil patolojinin ayak bileği olmadığı, ayak ile tibia arasındaki açının ekinde olmamasından anlaşılabilir. Bu ayrımda ayrıntılı fizik muayenenin önemi çok büyüktür.

yürüyüşü ise temel olarak salınım fazında oluşan bir bozukluktan kaynaklanır.

\section{Parmak Ucunda Yürüme}

Özellikle duruş fazını etkileyen iki yürüme bozukluğu arasındaki ayrım, ayakların basışları arasındaki farka bakılarak yapılabilir. Parmak ucunda yürüyüşün duruş fazında topuk vuruşu gerçekleşmez ve parmaklar ile yere temas hakimdir. ${ }^{[1]}$ Buna ekin pozisyonunda yürüme denir. Ancak, ekin pozisyonunda yürüme gerçek ve yalancı ekin pozisyonu olarak da ikiye ayrılmalıdır. ${ }^{[7]}$ Gerçek ekin pozisyonunda basışta, ayak yere ön ayak ile basmakta iken aynı zamanda ayak bileği tibiaya göre de plantar fleksiyondadır. Yanıltıcı veya yalancı ekin basışında ise ayak bileği tibiaya göre en azından nötral dizilim gösterir. Yani hastada mevcut diz veya kalça fleksiyonu, hastayı parmak ucunda yürümeye zorlayarak yanıltıcı bir ekin kontraktürü izlenimi vermektedir (Şekil 1). ${ }^{[6]}$

SP'li çocuklarda yalancı ekin basışı bozukluğunun birincil ve ikincil nedenleri, dizde ve/veya kalçadaki fleksiyonda basışa yol açan bozukluklardır. Bu hastalarda gerçekte bir ekin kontraktürü veya spastisitesi mevcut değildir. Dolayısı ile tedavide diz ve/veya kalça büküklügüne odaklanılmalıdır. Yanlışıkla yapılan ayak bileği cerrahileri sonrasında dizler bükük veya çömelerek yürüme bozukluğunun gelişmesi oldukça muhtemeldir. Bu durum çocuk büyüdükçe kendiliğinden de meydana gelebilir. ${ }^{[7-9]}$

Gerçek parmak ucu yürüyüşünü ise beraberindeki diz ve kalça pozisyonuna göre üçe ayırabiliriz. Parmak ucu yürüyüşe dizde veya kalçada herhangi bir ikincil problemin eşlik etmediği duruma basitçe "parmak ucu yürüme" denebilir (Şekil 2). Bu yürüme bozukluğunda birincil ve ikincil yürüme bozukluğu nedenleri ayak bileğinden kaynaklanır. Birincil olarak ayak bileğinde ekin spastisitesi, ikincil olarak da Aşil tendonu veya gastroknemius kası kontraktürü bu bozukluğa yol açacaktır (Şekil 3). Bu hastalarda üçüncül olarak ise bağ esnekliğine bağlı olarak orta ayakta bükülme bunun sonucunda kısa süreli de olsa topuk teması (beraberinde erken topuk kalkışı) veya öne hareketin sağlanması için anterior pelvik eğim görülebilir. Dolayısı ile bu yürüme 


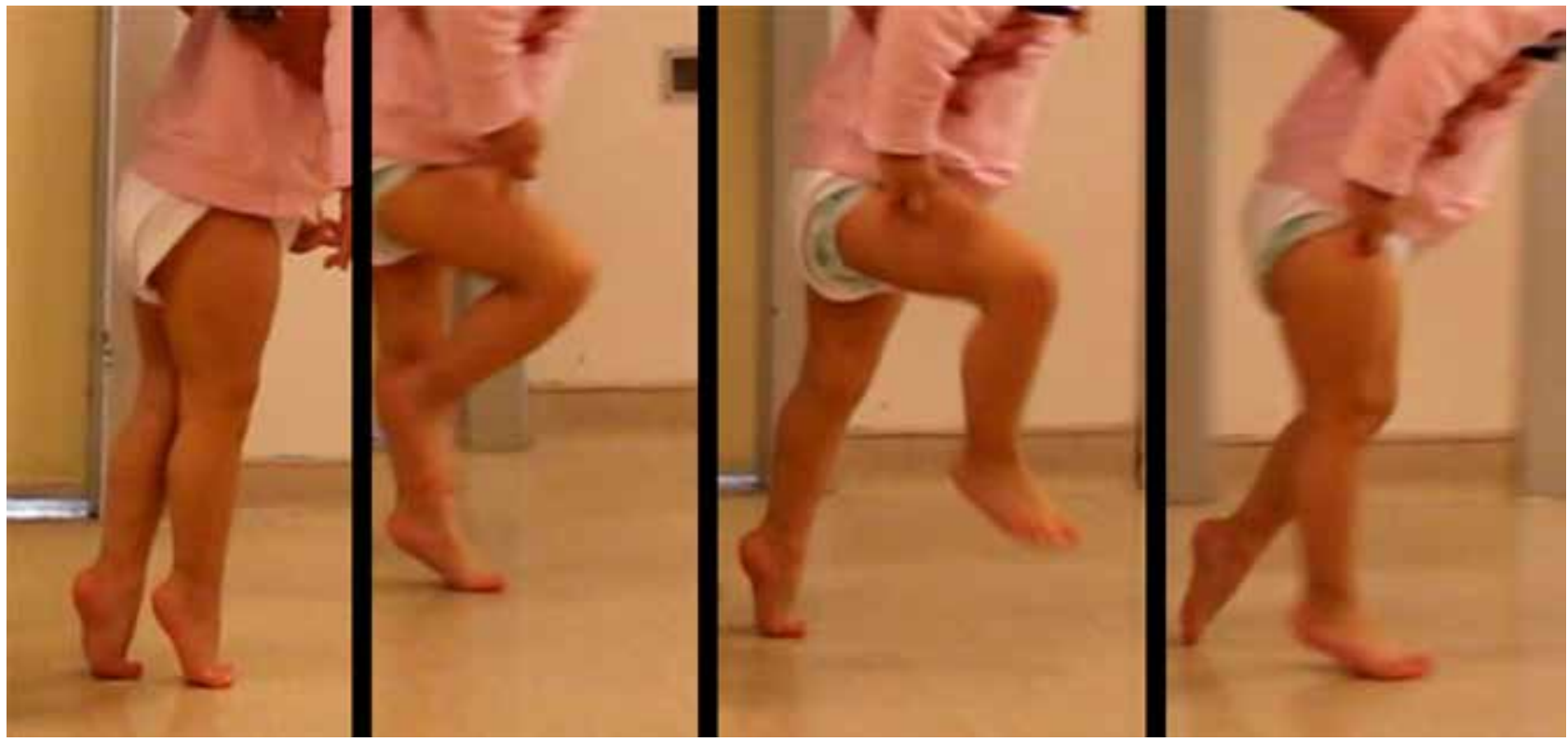

Şekil 2. Ayağın gerçek ekin pozisyonunda olduğu ve parmak ucunda yürüyen SP’li bir çocuğun yürüme fotoğrafları görülmekte. Diz ve kalça hareket açıklığında herhangi bir anormallik göze çarpmamaktadır. Topuk yürümenin herhangi bir anında yer ile temas edememekte, her zaman ön ayak ile temasın sağlandığı gözlenmektedir.

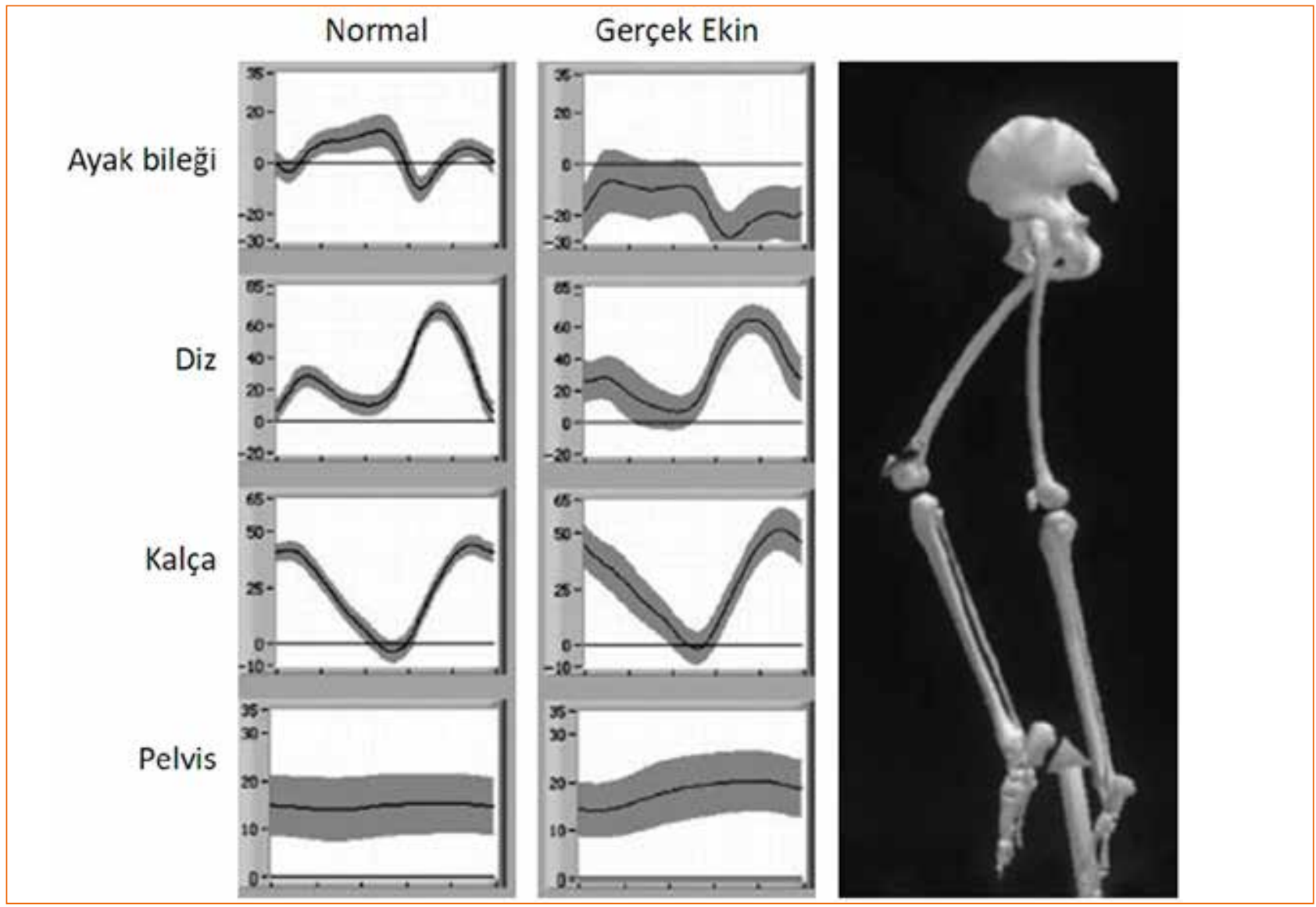

Şekil 3. Parmak ucunda yürüme gözlenen bir çocukta bilgisayarlı yürüme analizi sırasında elde edilen kinematik veriler görülmektedir. Ayak bileğinde hem basış hem de salınım fazlarında gözlenen ileri derecede dorsifleksiyon pozisyonunun yanında diz, kalça ve pelvis hareketlerinde normal ile kıyaslandığında önemli bir fark görülmemektedir. 


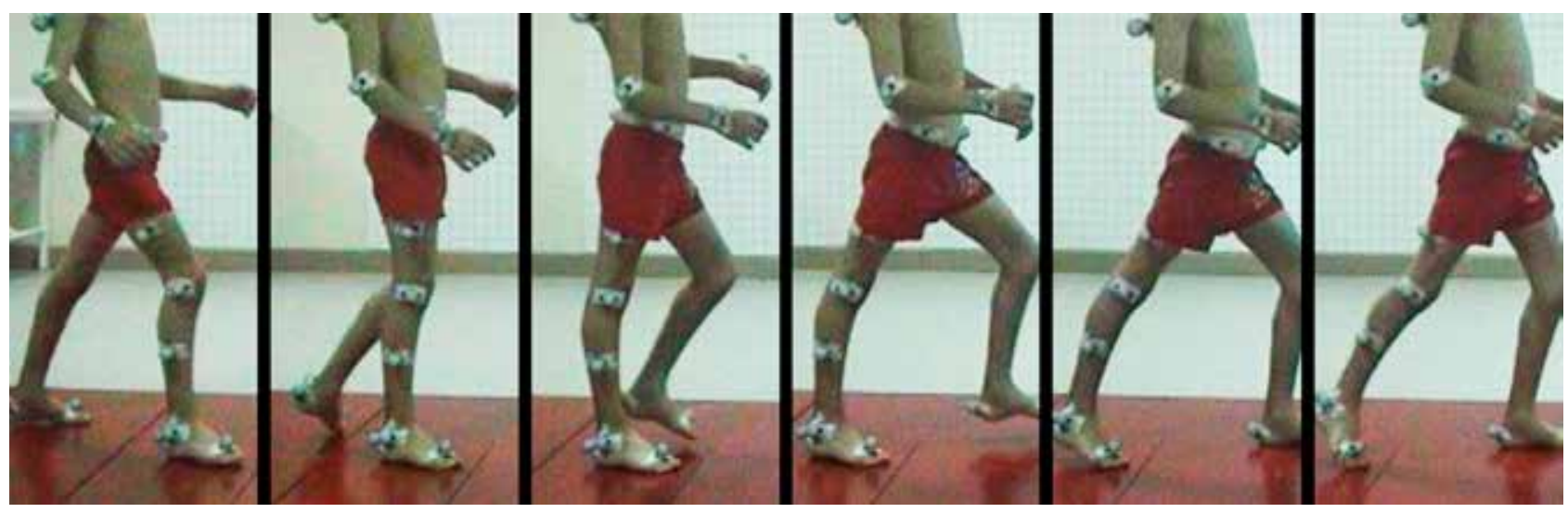

Şekil 4. Rekurvatumda (diz geri kaçarak) yürüyüş gösteren SP’li bir çocuğun sağ ayağının yürümenin basma aşamasındaki pozisyonları görülmektedir. Duruşun ortasında sağ dizin rekurvatum pozisyonu alışı açıkça görülüyor. Bu çocukta, ekin kontraktürünün nispeten daha az olması nedeniyle, basmanın ilk aşamalarında ayak yere plantigrad basabilmiştir. Daha sonraki aşamalarda ise bu basışı sürdürebilmek için dizin hiperekstansiyonuna ihtiyaç duymuştur.

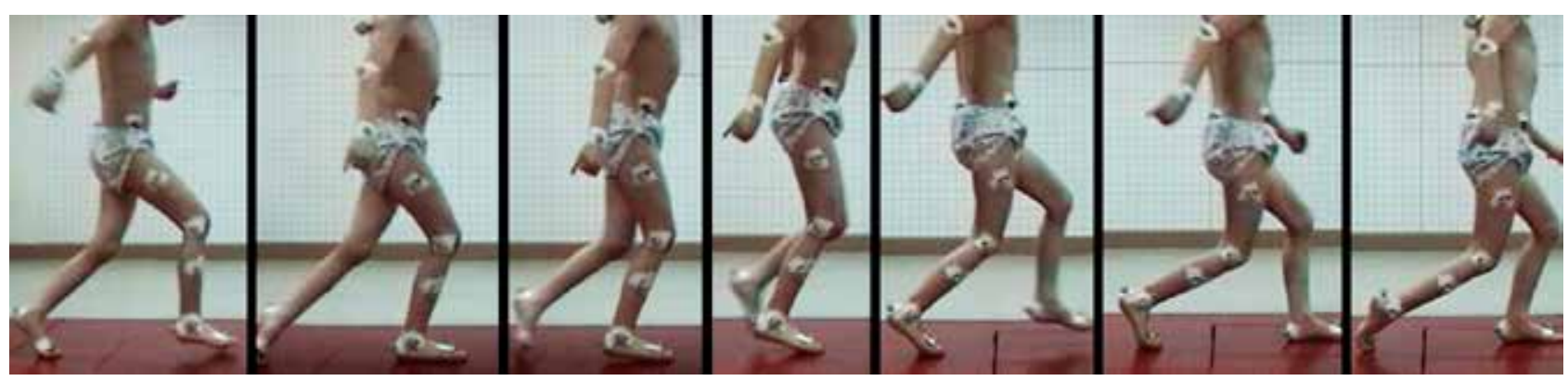

Şekil 5. Sıçrayarak yürüme gösteren SP’li bir çocuğun sağ alt ekstremitesinin yürümenin basma aşamalarındaki pozisyonu gösterilmiştir. Burada erken topuk kalkışı ile karakterize ayak bileği ekin deformitesi ve dizdeki fleksiyon deformiteleri açıkça görülmektedir.

bozukluğunun tedavisinde de buna göre bir yaklaşım izlenmelidir. Ön planda plantar fleksiyon spastisitesi tespit edildiyse botulinum toksin uygulamalarına başvurulması gerekirken, ekin kontraktürü tespit edildiğinde tenotomilere başvurulması uygun olacaktır. ${ }^{[10,11]}$ Tenotomi kararı verilirken ekin kontraktürünün kaynağı tespit edilmelidir. Bu amaçla, gastroknemius kası gerginliğinin Aşil tendonu kısalığından ayırt edilmesinde Silverskiöld testi, ayak arkasının varusa alınmasına dikkat edildiğinde ve aşırı kuwvet uygulanmadığında, etkili bir şekilde kullanılmaktadır. ${ }^{[11,12]}$

Gerçek ekin basışına diz ve/veya kalçada hiperekstansiyonun eşlik ettiği yürüme için ise yine parmak ucu yürüme tanımı kullanılabilir. Yani, yürüme bozukluğundaki birincil ve ikincil nedenler ayak bileği kaynaklıdır. Fakat bu durumda ayrıca telafi etmek amacıyla üçüncül olarak, plantar fleksiyon - diz ekstansiyonu fonksiyonel çifti nedeniyle, dizde hiperekstansiyon veya kalçada hiperekstansiyon görülecektir. ${ }^{[13]} \mathrm{Bu}$ sayede, gerçek ekin yürüyüşü olmasına rağmen, çocuklar basma aşamasının başında olmasa da ortasında topuğun yer ile temasını sağlayabilirler. Bu tip bir yürümeye "rekurvatum yürüyüşü" veya "diz geri kaçarak yürüyüş" adı verilir (Şekil 4). ${ }^{[1]}$ Bu yürüyüş bozukluğunda da öncelikli tedavi hedefi birincil ve ikincil nedenler olmalı üçüncül nedenlerin ise kendiliğinden düzeleceği ön görülmelidir. ${ }^{[11,12]}$

Parmak ucu yürüyüş gösteren bir hastada gerçek ekin basışına dizde ve/veya kalçada fleksiyonda basış eşlik ediyorsa, bu yürüyüş "sıçrayarak yürüyü̈ş” olarak tanımlanmalıdır (Şekil 5). Bu bozuklukta birincil ve ikincil nedenler ayak bileğinin yanı sıra dizde veya kalçada da mevcuttur (Şekil 6). Bu hastalarda tek aşamalı çok seviyeli cerrahi (single-event multi-level surgery -SEMLS) ile tek seansta tüm yürüme bozukluğu nedenlerine yönelik olarak cerrahiye başvurulmalıdır. Örneğin, sadece ayak bileği gevşetilmesinin ileride çömelerek yürümeye neden olabileceği veya sadece 


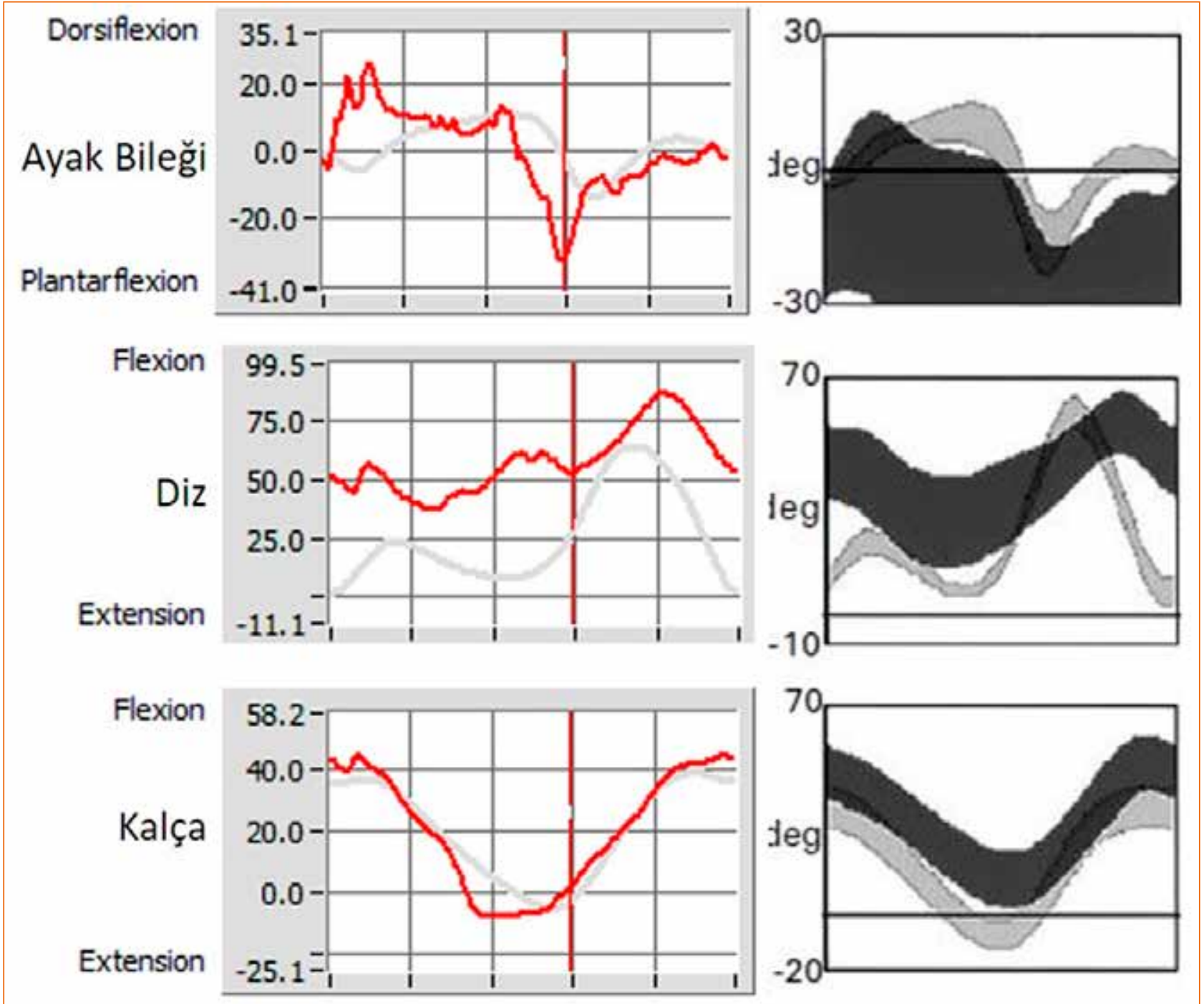

Şekil 6. Sıçrayarak yürümenin kinematik grafikleri görülüyor. Soldaki sütunda Şekil 5'teki hastanın yürüme analizi grafikleri görülmektedir. Basma fazı ortasında erken topuk kalkışı net olarak seçilebilmektedir. Dizde tüm basma periyodu boyunca fleksiyonun artmış olduğu, kalçada ise bir farklılık olmadığı gösterilmiştir. Erken topuk kalkışı yerine, gözle görülebilir ve ön ayağın yer ile temas ettiği ekin deformiteleri ile de karşılaşılabilir. Bu tip bir yürümenin görüntüsü de sağdaki sütunda örneklendirilmiştir.

dizlerdeki büküklüğün tedavi edilmesinin ileride sert diz yürüyüşüne veya genu rekurvatuma yol açabileceği unutulmamalıdır. ${ }^{[8]}$ Bu yürüme bozukluğu gibi nispeten daha karmaşık olgularda birincil, ikincil ve olası üçüncül nedenlerin ayrımının kesin olarak belirlenmesi ve tedavi etkinliğinin de değerlendirilmesi amacıyla bilgisayarlı hareket analizinden yararlanılması önerilebilir. ${ }^{[8,14,15]}$

\section{Çömelerek Yürüme (crouch gait)}

Bu yürüyüşün temel özelliği, ayak bileği plantar fleksiyon gücünde azalmanın ön planda olmasıdır. Bu hastalarda tüm basma aşamalarında düztaban şeklinde (pes planus veya pes planovalgus) veya topuk ile (pes kalkaneus) temas görülür. ${ }^{[1,16]}$ Yürümedeki ayak bileği plantar fleksiyonu - diz ekstansiyonu fonksiyonel çiftinin çalışmaması nedeniyle, özellikle büyüme çağındaki veya adolesan çocuklarda, diz ekstansörlerine binen yükten dolayı diz ekstansiyonunda kayıp ve diz bükük yürüyüş görülür (Şekil 7). ${ }^{[9]}$ Ayrıca, küçüklüğünde sıçrayarak yürüyüş gösteren çocuklarda da zamanla plantar fleksörlerin zayıflaması ve kilonun artması ile birlikte çömelerek yürümeye dönüş olduğu gösterilmiştir. ${ }^{[9]}$ Dolayısı ile, hastaların birincil ve 


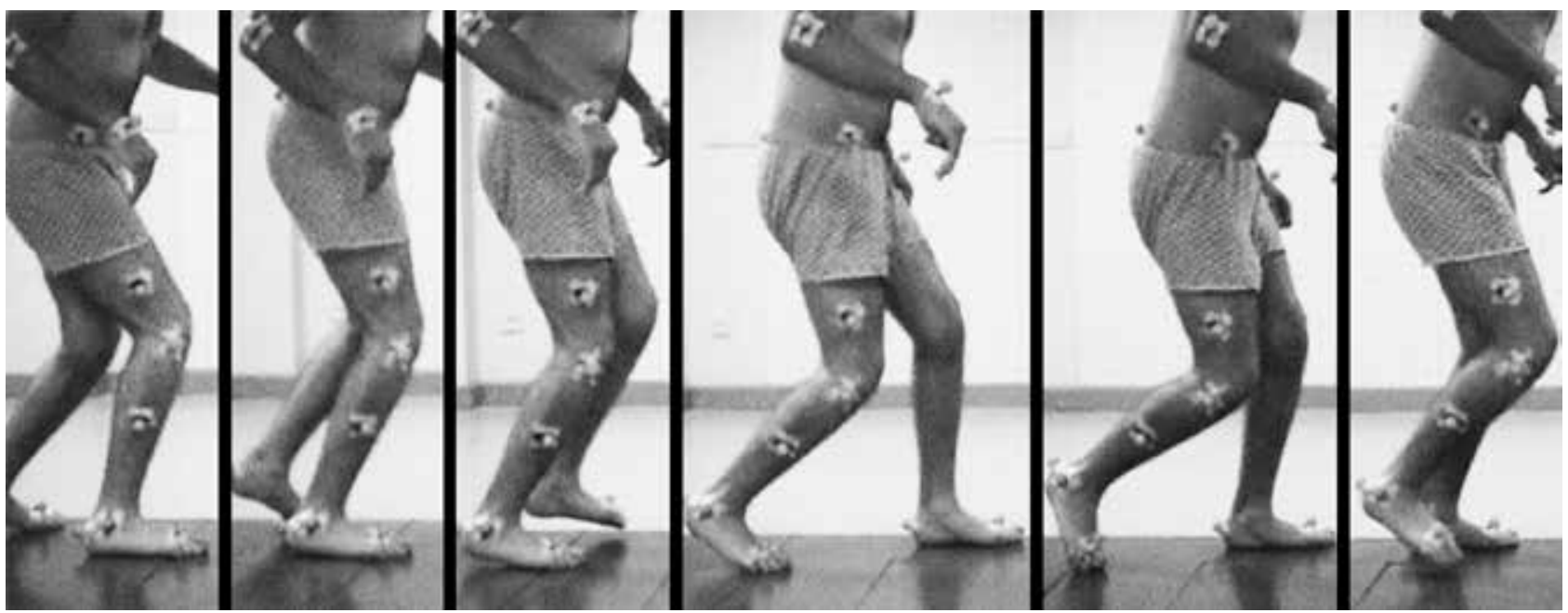

Şekil 7. Serebral palsili bir hastada çömelerek (crouch gait) yürüme bozukluğunun yürüme analizindeki görüntüleri görülmektedir. Ayağın plantar fleksiyonunda azaldığı ve tüm basma süresince dizlerde fleksiyonun arttığı gözlenebiliyor. Ek olarak, yürüme bozukluğunun telafi edilebilmesi için gövdenin öne eğilmiş olduğu ve kalçada da artmış fleksiyonun varlığı görülüyor.

ikincil yürüme bozuklukları ayak bileği ve diz kaynaklıdır. Birincil bozukluklar kas güçsüzlüğü (ayak bileği plantar fleksiyonu ve diz ekstansiyonu) ikincil bozukluklar ise eklem kontraktürleri (diz fleksiyon kontraktürü), kemiksel dizilim kusurları olarak tanımlanabilir (pes planovalgus). ${ }^{[17]}$

Ayak bileğinde plantar fleksiyon gücünde zayıflık olması ve dizlerde fleksiyon deformitesinin gelişmesi üzerine, ağırlık merkezinin ileri taşınması ve dize binen yükün azaltılması amacıyla telafi edici üçüncül bozukluklar gelişmiştir (Şekil 8). ${ }^{[6,9]}$ Bunlar, kalçada artmış fleksiyon, artmış anterior pelvik eğim veya gövdede öne eğilme olarak örneklenebilir. Bu telafi yöntemlerinin başarısı ise, hem dengeli yürüyüşün sağlanması hem de yapılan yürüme analizi çalışmalarının kinetik ve kinematik verileri ile belirlenir. Telafi edilmiş çömelerek yürüyüşte, üçüncül değişimler sayesinde, ağırlık merkezi diz merkezinden geçecek şekilde öne alınarak dizde eksternal fleksör moment ile internal ekstansör momentler azaltılır ve bu da basmanın ortasında diz eklemi üzerine binen yükü azaltarak daha dengeli ve nispeten daha az enerji saf eden bir yürüyüş kazandırır. Kalçanın veya gövdenin öne doğru yer değiştirmesi kalça ekleminde internal ekstansör momenti önemli ölçüde arttıracaktır ve bu nedenle de başarılı bir telafinin ana şartı sağlam güçlü kalça eklemine sahip olmaktır. Bu bağlamda, çömelerek yürümenin iyi tolere edildiği çocuklar genellikle aşırı kilolu olmayan, küçük, nispeten daha aktif ve kuvvetli olanlardır.
Yürüme bozukluğunun üçüncül bileşenleri çömelerek yürümeyi telafi edemediğinde, dizde internal ekstansör moment duruş boyunca devam etmekte, dizden yük alınamamakta, ağırlık merkezi öne kaydırılamamaktadır. ${ }^{[6,9]} \mathrm{Bu}$ durum da hastalarda, patellar avulsiyon kırıkları, patella alta, patellofemoral ağrılar, yürürken çökmede/çömelmede ilerleme ve dizler üzerinde yürüme eğilimi olarak karşımıza çıkacaktır. ${ }^{[17]}$

Oldukça karmaşık bir patofizyolojiye sahip çömelerek yürüme bozukluğunun tedavisinde amaç, ayak bileği ve dizdeki birincil ve ikincil patolojileri çözmektir. Bilgisayarlı yürüme analizi kinetik ve kinematik değerlendirmelerinin ışığında, tek aşamalı çoklu seviye cerrahileri sayesinde, yürüme daha iyi bir duruma getirilebilmektedir. ${ }^{[3,8,16,18]}$ Tedavi sonrasında ayak bileği dorsifleksiyonu azaltılabilir ve diz ile kalça ekstansiyonu iyileştirilebilirken, istenmeyen bir sonuç olarak anterior pelvik eğimin artması da tanımlanmıştır ve tedavinin etkinliğini etkilemesi muhtemeldir. Bu konu üzerine çalışmalar devam etmektedir. ${ }^{[16-18]}$

\section{Sert Diz Yürüyüşü}

Sert diz yürüyüşü, salınım fazındaki tepe diz fleksiyonundaki azalma veya gecikme ile karakterize, karakteristik olarak ayağın yerden kaldırılmasında veya bir engelin aşılmasında zorluğun olduğu, yürüme hızının azaldığı yürüme bozukluğudur (Şekil 9). ${ }^{[1,15]}$ Bu yürüme şeklinin değerlendirilmesinde de, bilgisayarlı yürüme analizinin yeri özellikle diz ve kalça kaynaklı sert diz yürüyüş şekillerinin ayrımına varılmasında çok önemlidir. 


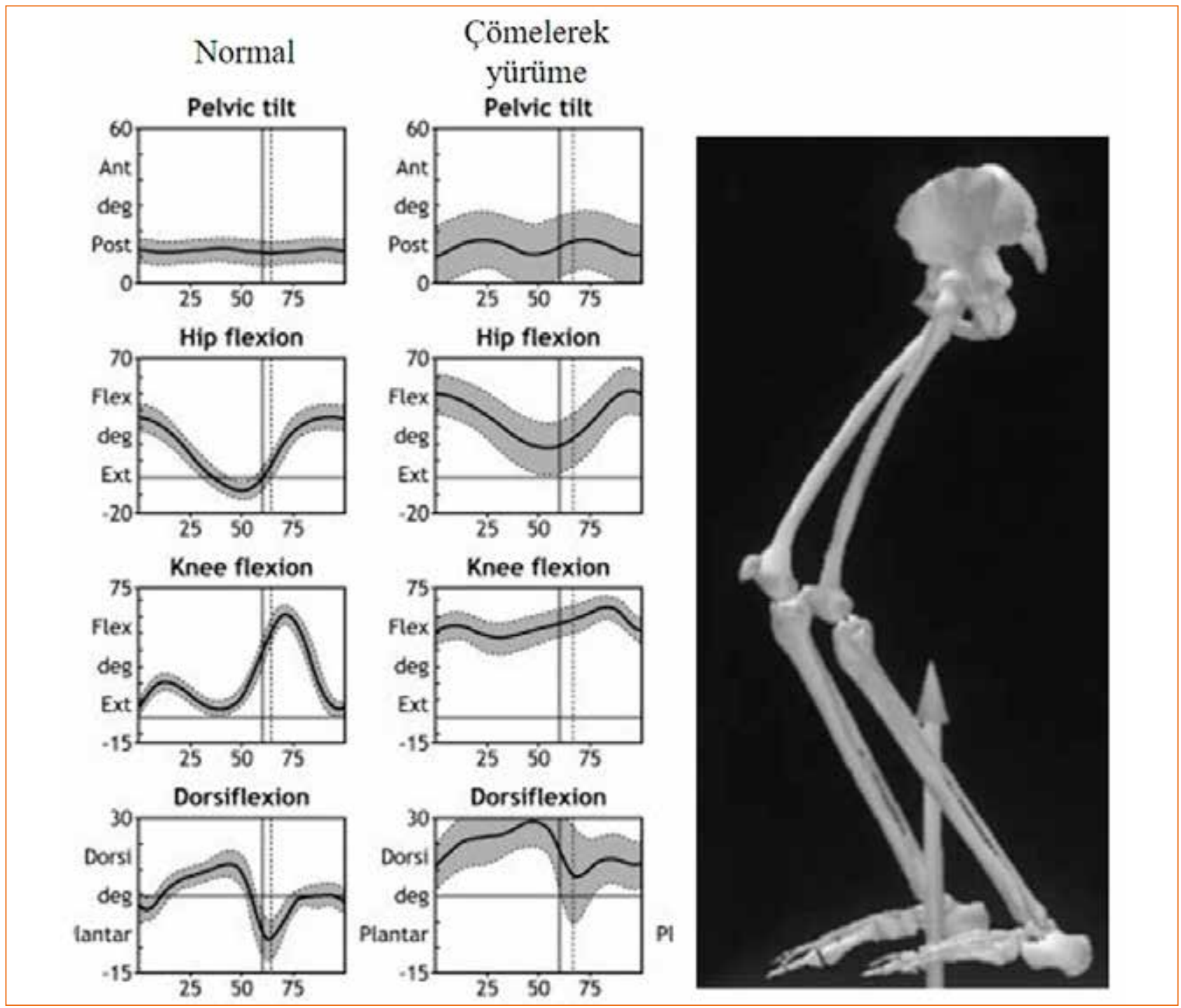

Şekil 8. Çömelerek yürüme bozukluğu olan SP'li bir çocuğun kinematik verileri görülmektedir. Ayak bileğinde dorsifleksiyonun ve dizlerde ise fleksiyonun artmış olması bu yürüme bozukluğunun klasik özellikleridir. Normal yürüme analizi grafikleri ile kıyaslandığında, kalçanın artmış fleksiyonu ve pelviste artmış öne eğim ile bozukluğun kısmen de olsa telafi edilmeye çalışıldığı görülüyor.

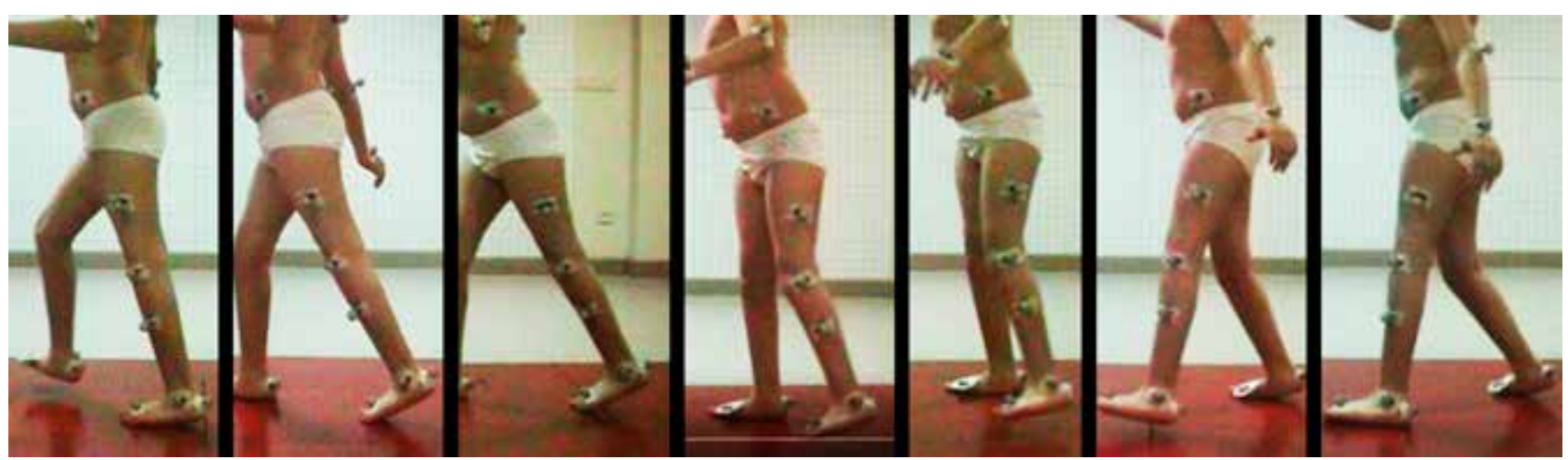

Şekil 9. Sert diz yürüyüşü gösteren SP’li bir çocuğun sol alt ekstremitesinin salınım fazındaki hareketleri gösterilmiştir. Salınım fazı boyunca diz fleksiyonunda belirgin azalmanın olduğu görülüyor. Hastanın, ayağını yerden kaldırmak için yetersiz kalan sol kalça fleksiyonun yanında sol tarafta pelvisin elevasyonuna da ihtiyaç duyduğu gözleniyor. 


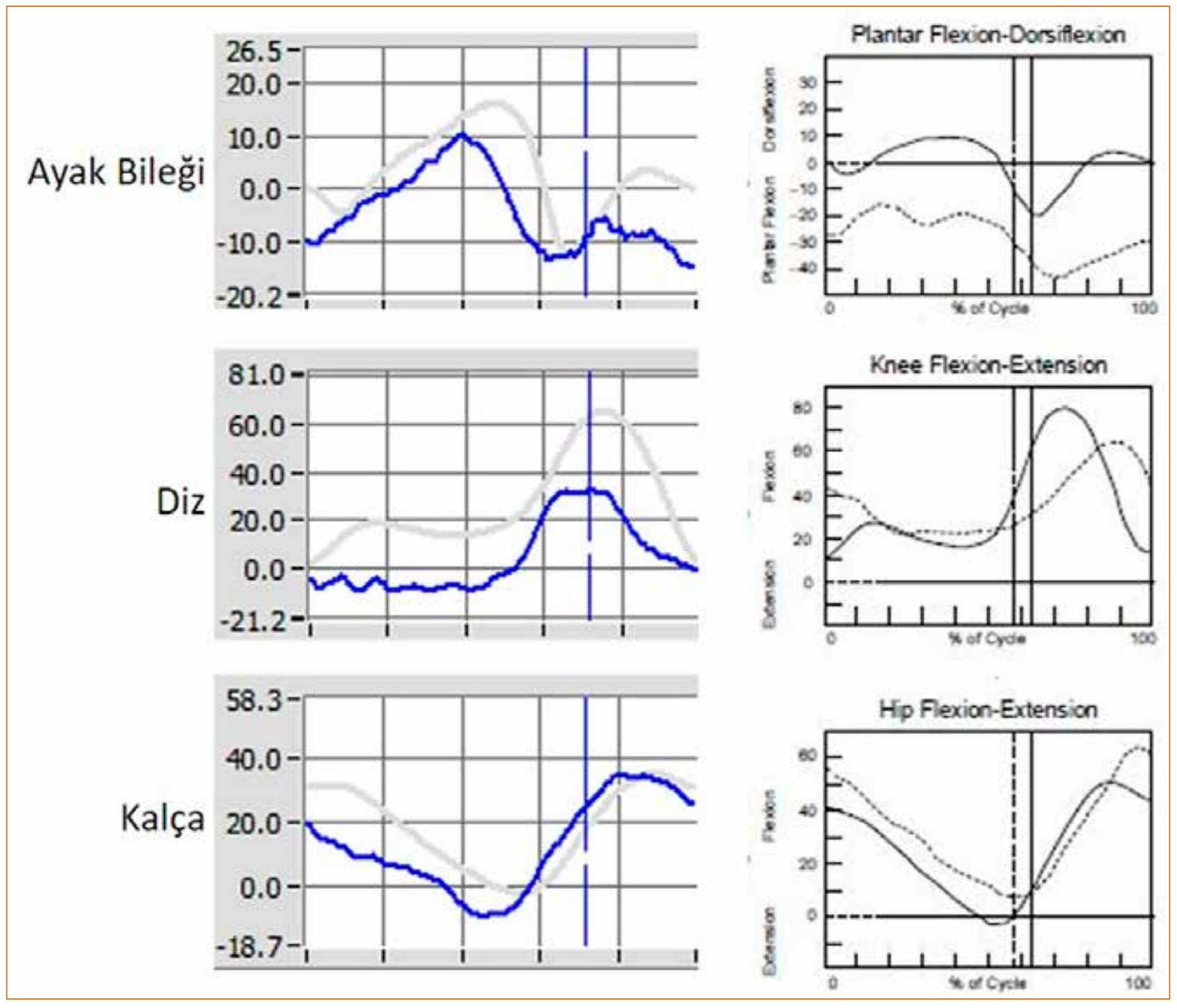

Şekil 10. Dizdeki fleksiyon kaybından kaynaklı sert diz yürüyüşündeki ayak bileği, diz ve kalça kinematik verileri gösterilmiştir. Sol sütundaki yürüme analizinde belirgin bir ayak bileği yürüme bozukluğu tespit edilememiştir. Sağ sütundaki başka bir hastanın yürüme analizinde ise dizde salınım fazındaki geç ve düşük fleksiyon aktivitesine tüm yürüme döngüsü boyunca ayak bileğinde ekin deformitesinin eşlik ettiği gösterilmiştir.

Diz kaynaklı sert diz yürüyüşünde temel olarak salınımın başında kalça kinematik ve kinetik profili normal veya normale yakındır (Şekil 10). Bu durumda yürüme bozukluğunun birincil nedeninin dizde ekstansiyon yönünde olduğu (rektus spastisitesi gibi) sonucuna varılmalıdır. Bu hastalarda yapılan tek seviyeli cerrahi (rektus femoris transferi) ile uzun dönemde olumlu sonuçlar alındığı gösterilmiştir. [15]

Kalça kaynaklı sert diz yürüyüşünde ise yine dizde salınım fazında değişiklikler vardır; ancak bu değişikliklerin hemen öncesinde duruş fazından salınıma geçişte kalça kinematik (kalçada fleksiyon artışında yavaşlama ve bu grafiğin eğiminde azalma) ve kinetik (kalçada azalmış internal fleksiyon momenti) verilerinde bozulma tespit edilir. Bu durumda, kliniğin birincil nedeni kalçadaki zayıflık, kas koordinasyon bozukluğu olarak belirlenir. Dizdeki fleksiyon momentindeki ve fleksiyon derecesindeki azalmalar da bu birincil değişimin bir sonucudur ve bu hastalarda kalça fleksör gücünü iyice azaltacağı için, rektus femoris transferi uygulanmasından kaçınılmalıdır. ${ }^{[19]}$ 


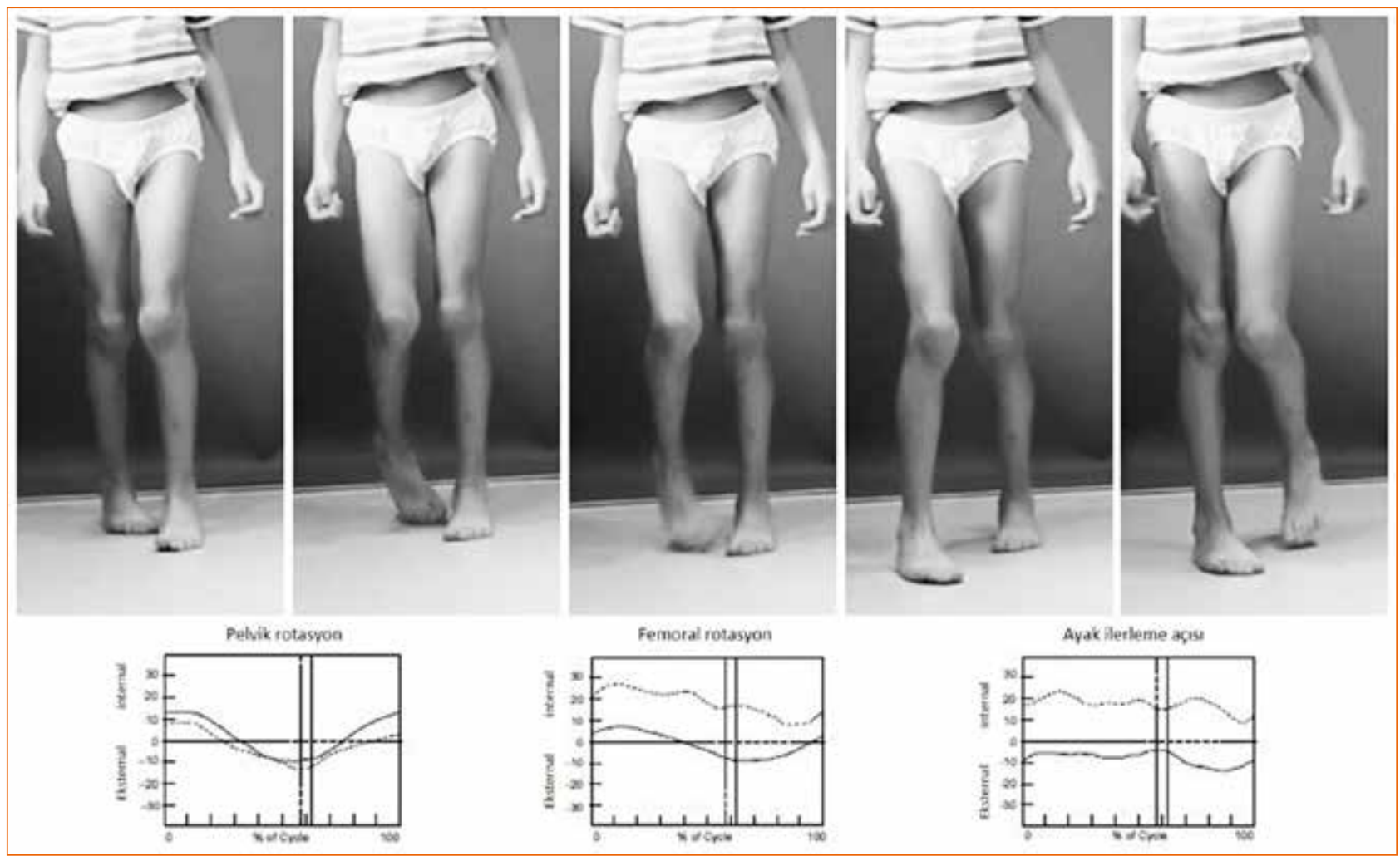

Şekil 11. SP'li bir çocukta artmış femoral anteversiyona bağlı olarak internal rotasyonda transvers plan yürüme bozukluğu (içe dönük basma) gösterilmiştir. Basma aşamasının ortasında dizin içe dönük duruşu ve bununla aynı doğrultuda içe dönük olarak duran ayağın pozisyonu gözlemsel olarak rotasyonel bozukluğun femurdan kaynaklandığını ifade eder. Ancak, transvers plandaki yürüme bozukluklarının değerlendirmesinde fizik muayene ve gözlemin yanı sıra bilgisayarlı yürüme analizlerine de başvurmak gereklidir.

\section{SEREBRAL PALSIDE YÜRÜMENIN TRANSVERS DÜZLEMDEKI BOZUKLUKLARI}

SP'li çocukların yürüyüşlerindeki transvers düzlem bozuklukları temel olarak içe, dışa veya bunların bir kombinasyonu sonucu nötral rotasyonda ilerleme açıları ile birlikte olan yürüyüşler olarak sınıflandırılabilir. ${ }^{[20]}$ Bunların gözlemsel yürüme değerlendirmesi ile sağlıklı tespiti çok tecrübeli çocuk ortopedistlerinin ayrıntılı fizik muayeneleri ile tespit edilebilirken, bilgisayarı yürüme analizi ile tanı ve tedavi seçimi oldukça kolaylaşmıştır. Bu bozukluklar, özellikle yürüme sırasında kaldıraç kolu fonksiyon bozukluğuna yol açarak yürümedeki enerji sarfiyatını arttırır ve üçüncül bozuklukların oluşmasında rol oynar.

Genel olarak bu rotasyonel problemler, ilerleme açısını temel almasından dolayı, yürümenin basma aşaması için tanımlanmıştır. Bunlar ayrıca, tek seviye ve çoklu seviye kaynaklı rotasyonel bozukluklar olarak da sınıflanabilir.
Transvers planda eksternal veya internal rotasyonel problemlerin birincil nedenleri ayak, ayak bileği, diz veya kalçadaki spastisiteler iken, kemiklerdeki rotasyonel deformiteler (artmış femoral anteversiyon, tibial torsiyon gibi) veya alt ekstremite dizilim kusurları (ayakta varus, metatarsus adduktus gibi) ikincil nedenler olarak sayılabilir (Şekil 11). ${ }^{[20]}$ Bu bozukluklar tek seviyeli olabileceği gibi birden çok seviyeli de olabilir. Dolayısı ile, tutulan her bir seviyeye yönelik olarak (derotasyon osteotomisi gibi) gereğinde tek aşamalı çoklu seviye cerrahisine de başvurulmalıdır. Öte yandan, özellikle obez çocuklarda bacakların kalın olmasından dolayı yürüme sırasında kalçaların abduksiyonda ve hafif eksternal rotasyonda olmaları gözleme dayalı değerlendirmelerde rotasyonel profil ile ilgili yanlış sonuçlara yol açabilir. ${ }^{[6]}$

Normal bir ilerleme açısına sahip bir çocuğun değerlendirmesinde görsel olarak basma aşamasında dizin içe veya dışa dönük durması alt ekstremitede bileşik 


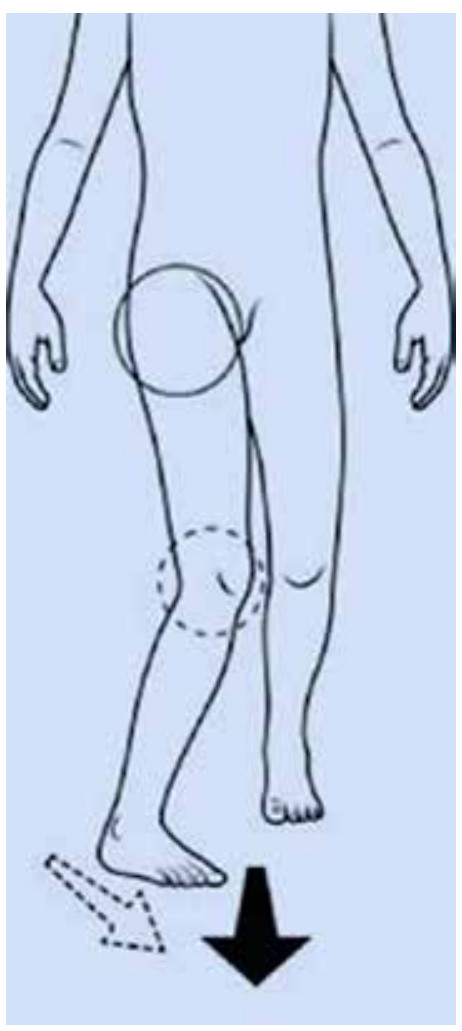

Şekil 12. Kompleks dizilim kusuru (miserable malalignment) çizim olarak gösterilmiştir. SP'li çocuklarda sıklıkla karşılaşılan artmış femoral anteversiyona tibiada eksternal torsiyonun eşlik ettiği olguların bir kısmında ayak ilerleme açısı yürüme sırasına normal olarak görülebilir. Bu gibi durumların fark edilebilmesi için yürümenin gözlemlenmesi sırasında ayak ilerleme açısının incelenmesinin yanında basış sırasında dizlerin rotasyonlarına da dikkat edilmesi gereklidir.

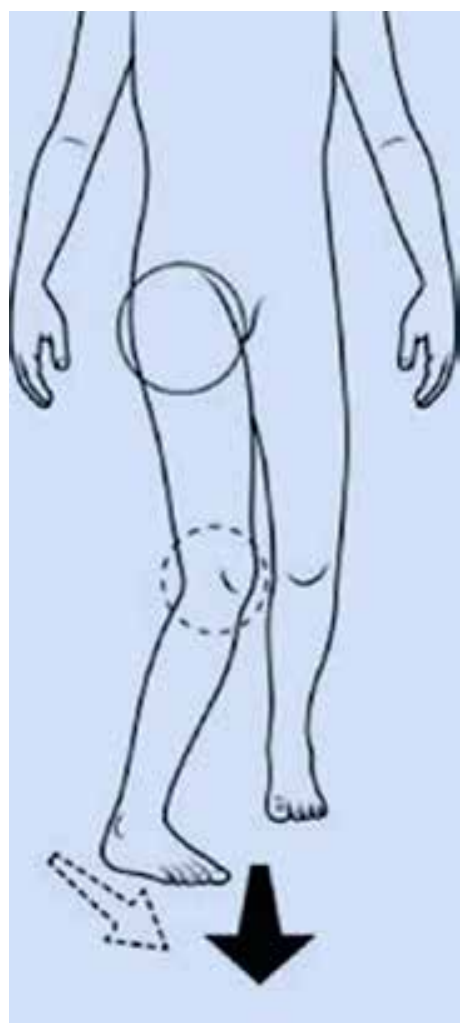

Şekil 13. Yürüme sırasında koronal planda olduğu düşünülen bir bozukluğun transvers ve sagittal düzlemlerdeki bozuklukların bu plana izdüşümleri şeklinde olabileceği, bu çizim ile anlatılmıştır. Illk bakışta dizde valgus deformitesi olduğu düşünülebilecek bir çocuğun, diğer düzlemlerdeki yürüme analizi verileri incelendiğinde ve ayrıntılı bir muayene yapıldığında dizin koronal düzlemde tamamen normal veya normale yakın olduğu; ancak kalçada artmış bir femoral anteversiyon ve artmış diz fleksiyonunun olduğu fark edilebilir. Bu nedenle, yürüme bozukluklarının tam olarak anlaşılmasında ayrıntılı muayene, gözlemsel analiz ve bilgisayarlı yürüme analizi bir arada kullanılmalıdır. dizilim kusuru (miserable malalignment) olduğu şüphesini doğurur. Bu durum da SP'li çocuklarda genellikle dizin içe dönüklüğü şeklindedir. Tanıda, genellikle gözlemsel analizde atlanabildiği için, bilgisayarlı yürüme analizlerinden yarar görülür. Altta yatan ikincil nedenler femurda artmış anteversiyon veya yetişkin rotasyonel dizilimine kavuşamamış olması ve tibiada artmış eksternal torsiyon varlığıdır. Bunlar bir arada ve birbirini eşitleyecek derecede veya hasta tarafından tolere edilebilecek derecede ise nötral ilerleme açısı görülecektir (Şekil 12). Bu durum Q açısı üzerine olumsuz etkisi nedeniyle femur üzerinde patellar kayma problemlerine, dizde aşırı yüklenmeye ve patellofemoral ağrılara yol açabilmektedir. ${ }^{[21]}$

\section{SEREBRAL PALSIDE YÜRÜMENIN KORONAL DÜZLEMDEKI BOZUKLUKLARI}

SP'li çocuklarda alt ekstremitelerde koronal düzlemde gerçek dizilim kusuru, hastalığa bağlı olarak beklenen bir bozukluk değildir. Koronal düzlemde olduğu gözlemlenen çoğu yürüme bozukluğu, sagittal veya transvers düzlemdeki bozuklukların koronal plandaki izdüşümlerinin yanıltıcı görüntüsüdür (Şekil 13). ${ }^{[6]}$ Örneğin, kalçada artmış anteversiyon nedeni ile internal rotasyonda ilerleme açısı ile yürüyen bir çocuktaki aynı zamanda var olan bir diz fleksiyon kontraktürü, özellikle tecrübesiz hekimlerce değerlendirildiğinde ve yürüme analizi yapılmadığında, koronal düzlemde dizde valgus deformitesi varlığı olarak yanlış tanı alabilmektedir.

Sıklıkla önem arz eden adduktor kas grubundaki spastisite veya kontraktürler nedeniyle gelişen makaslayarak yürüme de bir koronal düzlem bozukluğudurve görüntü olarak kalçada artmış anteversiyon ve artmış fleksiyon ile abartılı şekilde kendini gösterebilmektedir. Bu durumda ayrıntılı muayene, görüntüleme yöntemleri ve gereğinde yürüme analizi ile birincil veya ikincil bozukluklar ve gerçek şiddetleri tespit edilerek hedefe yönelik tedaviler yapılabilir.

Diğer gerçek koronal düzlem bozuklukları, ikincil nedenlere dayalı ekstremite kemiksel dizilim kusurları olarak kendini gösterebilir (ayak bileği valgus deformitesi gibi). Bunlar ise özellikle basma fazında değerlendirilebilir ve yürümenin düzeltilmesinde kontraktürlere veya kemiksel deformitelere yönelik olarak düzeltici cerrahilere baş vurulması yarar sağlayacaktır. Bir diğer olası koronal düzlem yürüme bozukluğu ise pelvis oblikliğidir. Bu problem özellikle hemiplejik hastalarda 
tek tarafta var olan bir ekin veya diz fleksiyon kontraktürü gibi ikincil nedenlerin bir yansıması olarak alt ekstremitede oluşan yanıltıcı boy farkı sonucunda gelişebilmektedir. Bu durumda da ikincil nedenlere yönelik cerrahiler ve gereğinde tek aşamalı çoklu seviye cerrahileri ile yürüme düzelebilir. ${ }^{[6]}$

\section{KAYNAKLAR}

1. Sutherland DH, Davids JR. Common gait abnormalities of the knee in cerebral palsy. Clin Orthop Relat Res 1993;(288):13947. Crossref

2. Dobson F, Morris ME, Baker R, Graham HK. Gait classification in children with cerebral palsy: a systematic review. Gait Posture 2007;25(1):140-52. Crossref

3. Davids JR, Ounpuu S, DeLuca PA, Davis RB 3rd. Optimization of walking ability of children with cerebral palsy. Instr Course Lect 2004;53:511-22.

4. Chambers HG, Sutherland $\mathrm{DH}$. A practical guide to gait analysis. J Am Acad Orthop Surg 2002;10(3):222-31. Crossref

5. Riad J, Haglund-Akerlind Y, Miller F. Classification of spastic hemiplegic cerebral palsy in children. J Pediatr Orthop 2007;27(7):758-64. Crossref

6. Davids JR, Bagley AM. Identification of common gait disruption patterns in children with cerebral palsy. J Am Acad Orthop Surg 2014;22(12):782-90. Crossref

7. Rodda JM, Graham HK, Carson L, Galea MP, Wolfe R. Sagittal gait patterns in spastic diplegia. J Bone Joint Surg $\mathrm{Br}$ 2004;86-B(2):251-8. Crossref

8. Dreher T, Vegvari D, Wolf SI, Geisbüsch A, Gantz S, Wenz W, Braatz F. Development of knee function after hamstring lengthening as a part of multilevel surgery in children with spastic diplegia: a long-term outcome study. J Bone Joint Surg Am 2012;94(2):121-30. Crossref

9. Kedem P, Scher DM. Evaluation and management of crouch gait. Curr Opin Pediatr 2016;28(1):55-9. Crossref

10. Koman LA, Paterson Smith B, Balkrishnan R. Spasticity associated with cerebral palsy in children: guidelines for the use of botulinum A toxin. Paediatr Drugs 2003;5(1):11-23. Crossref
11. Barouk P, Barouk LS. Clinical diagnosis of gastrocnemius tightness. Foot Ankle Clin 2014;19(4):659-67. Crossref

12. Cazeau C, Stiglitz Y. Effects of gastrocnemius tightness on forefoot during gait. Foot Ankle Clin 2014;19(4):649-57. Crossref

13. Baddar A, Granata K, Damiano DL, Carmines DV, Blanco JS, Abel MF. Ankle and knee coupling in patients with spastic diplegia: effects of gastrocnemius-soleus lengthening. J Bone Joint Surg Am 2002;84-A(5):736-44. Crossref

14. Dreher T, Buccoliero T, WolfSI, Heitzmann D, Gantz S, Braatz F, Wenz W. Long-term results after gastrocnemius-soleus intramuscular aponeurotic recession as a part of multilevel surgery in spastic diplegic cerebral palsy. J Bone Joint Surg Am 2012;94(7):627-37. Crossref

15. Dreher T, Wolf SI, Maier M, Hagmann S, Vegvari D, Gantz S, Heitzmann D, Wenz W, Braatz F. Long-term results after distal rectus femoris transfer as a part of multilevel surgery for the correction of stiff-knee gait in spastic diplegic cerebral palsy. J Bone Joint Surg Am 2012;94(19):e142(1-10). Crossref

16. Rodda JM, Graham HK, Nattrass GR, Galea MP, Baker R, Wolfe R. Correction of severe crouch gait in patients with spastic diplegia with use of multilevel orthopaedic surgery. J Bone Joint Surg Am 2006;88(12):2653-64. Crossref

17. Joseph B, Reddy K, Varghese RA, Shah H, Doddabasappa SN. Management of severe crouch gait in children and adolescents with cerebral palsy. J Pediatr Orthop 2010;30(8):832-9. Crossref

18. StoutJL, Gage JR, Schwartz MH, NovacheckTF. Distal femoral extension osteotomy and patellar tendon advancement to treat persistent crouch gait in cerebral palsy. J Bone Joint Surg Am 2008;90(11):2470-84. Crossref

19. Reinbolt JA, Fox MD, Schwartz MH, Delp SL. Predicting outcomes of rectus femoris transfer surgery. Gait Posture 2009;30(1):100-5. Crossref

20. Rethlefsen SA, Healy BS, Wren TA, Skaggs DL, Kay RM. Causes of intoeing gait in children with cerebral palsy. J Bone Joint Surg Am 2006;88(10):2175-80. Crossref

21. Bruce WD, Stevens PM. Surgical correction of miserable malalignment syndrome. J Pediatr Orthop 2004;24(4):3926. Crossref 